\title{
Problem With Parents In Online Learning Assistance For Children Aged 4-5 Years During the COVID-19 Pandemic
}

\author{
Budi Dyah Lestari, Hanifatun Nisak, Sri Setiyo Rahayu, Elizabet Petra Fridolina
}

PAUD Sekar Nigari Semarang

\begin{tabular}{l}
\hline Info Articles \\
\hline Sejarah Artikel: \\
Disubmit 28 Juli 2021 \\
Direvisi 29 Juli 2021 \\
Disetujui 31 Juli 2021 \\
\hline Keywords: \\
Online Learning, Parents, And \\
Early Childhood
\end{tabular}

Early Childhood

\begin{abstract}
Abstrak
Permasalahan dunia pendidikan adalah proses pembelajaran yang belum seragam, baik standar maupun kualitas hasil belajar yang diinginkan. Hal ini tentu dirasakan berat oleh pendidik dan peserta didik. Khusus bagi pendidik dituntut untuk kreatif dalam menyampaikan materi melalui media pembelajaran online. Hal ini perlu disesuaikan pula dengan tingkat pendidikan dalam kebutuhannya. Hasil survei di 98 negara mengidentifikasi prioritas sebagai berikut: memastikan pembelajaran bagi anak-anak, memberikan dukungan kepada anak-anak yang tidak mendapatkan fasilitas, memberikan dukungan kepada guru dalam bentuk kedokteran dan kesehatan mental, merevisi prosedur kelulusan, memastikan integritas penilaian, menentukan kurikulum yang sesuai, dan memberikan bantuan sosial. dan makanan untuk anak-anak. Penelitian ini menjadi solusi yang sangat penting dilakukan dalam memahami bagaimana memahami kebutuhan orang tua dalam mendampingi anaknya belajar di rumah menggantikan peran guru di masa pandemi Covid-19 dengan metode pembelajaran online dan variasi pembelajaran lainnya, salah satunya solusinya adalah melalui kunjungan rumah.
\end{abstract}

\section{Abstract}

The problem with the world of education is that the learning process is not yet uniform, both the standards and the quality of the desired learning outcomes. This is certainly felt heavy by educator s and students. Especially for educators, they are required to be creative in delivering material through online learning media. This needs to be adjusted also to the level of education in its needs. The survey results in 98 countries identified the following priorities: ensuring learning for children, providing support to children who do not get facilities, providing support to teachers in the form of medicine and mental health, revising graduation procedures, ensuring the integrity of assessments, determining appropriate curricula, and providing social assistance. and food for children. This research is a very important solution to do in understanding how to understand the needs of parents in accompanying their children to study at home replacing the role of the teacher during the Covid19 pandemic with online learning methods and other variations of learning, one of the solutions is through home visits.

\footnotetext{
Alamat Korespondensi:

E-mail: alamat@email.mu
}

p-ISSN XXXX-XXX e-ISSN XXXX-XXX 


\section{PENDAHULUAN}

Pendidikan merupakan keseluruhan proses dimana seseorang mengembangkan kemampuan, sikap, dan bentuk-bentuk tingkah laku yang bernilai positif. Hal itu untuk menjalankan fungsi kemanusiaan yang diemban sebagai seorang hamba di hadapan Sang pencipta. Pendidikan sangat penting bagi kehidupan, bahkan tuntutan akan pentingnya pendidikan semakin besar mengingat arus perkembangan dunia yang semakin cepat. Pendidikan juga diartikan sebagai proses pembinaan dan bimbingan yang dilakukan seseorang secara terus menerus kepada anak didik untuk mencapai tujuan pendidikan (Bisri, 2013). Menurut Azra, pendidikan merupakan suatu proses penyiapan generasi muda untuk menjalankan kehidupan dan memenuhi tujuan hidupnya secara lebih efektif dan efisien (Azra, 2000).

Adanya pandemi Covid-19 yang melanda dunia termasuk Indonesia, berdampak pada berbagai aspek kehidupan salah satunya pendidikan. Maka lembaga pendidikan mengharuskan menjalankan proses kegiatan pembelajaran secara jarak jauh, yakni siswa belajar dan guru mengajar harus tetap berjalan meskipun peserta didik berada di rumah. Akibatnya, pendidik dituntut mendesain pembelajaran dengan memanfaatkan media daring (online). Hal Ini sesuai dengan keputusan Menteri Pendidikan dan Kebudayaan Republik Indonesia terkait Surat Edaran Nomor 4 Tahun 2020 tentang Pelaksanaan Kebijakan Pendidikan dalam Masa Darurat Penyebaran Covid-19. Berbagai inisiatif dilakukan untuk memastikan kegiatan belajar tetap berlangsung meskipun tidak adanya sesi tatap muka langsung. Teknologi, lebih spesifiknya internet, ponsel pintar, dan laptop sekarang digunakan secara luas untuk mendukung pembelajaran jarak jauh

Hasil survey di 98 negara mengidentifikasi prioritas berikut: memastikan pembelajaran untuk anak, memberikan dukungan kepada anak yang tidak mendapatkan fasilitas, memberikan dukungan kepada guru berupa obat dan kesehatan mental, merevisi pelaksaan kelulusan, memastikan integritas penilaian, menentukan kurikulum yang sesuai, dan menyediakan bantuan sosial dan makanan untuk anak (Reimers \& Schleicher, 2020). Memastikan pembelajaran anak memerlukan peran aktif orang tua sebagai pengganti guru dirumah. Pada masa pandemic dimana anak tidak diijinkan untuk bersekolah maka anak hanya terakses dengan keluarga. Orang tua diharapkan mampu untuk mendukung pembelajaran dengan membantu mendampingi anak belajar dari rumah.

Problematika dunia pendidikan yaitu belum seragamnya proses pembelajaran, baik standar maupun kualitas capaian pembelajaran yang diinginkan. Hal ini tentu dirasa berat oleh pendidik dan peserta didik. Terutama bagi pendidik, dituntut kreatif dalam penyampaian materi melalui media pembelajaran daring. Ini perlu disesuaikan juga dengan jenjang pendidikan dalam kebutuhannya. Dampaknya akan menimbulkan tekanan fisik maupun psikis (mental). Maka dari itu, pemikiran yang positif, kreatif dan inovatif dapat membantu mengatasi berbagai problematika dalam proses pembelajaran jarak jauh dengan menerapkan media pembelajaran daring yang menyenangkan, sehingga menghasilkan capaian pembelajaran yang tetap berkualitas. pembelajaran jarak jauh dengan menggunakan media daring mengharapkan siswa bisa mengikuti pembelajaran dengan maksimal (Jaelani dkk, 2020).

Adapun Orang tua mempunyai tugas yang mendasar dalam sistem pertumbuhan dan perkembangan anaknya. Didikan baik dan buruk yang diberikan orang tua kepada anak berpengaruh terhadap pertumbuhan dan perkembangan anak. Dan lingkungan bagi setiap anak adalah keluarga, segala tingkah laku yang muncul pada diri anak akan mencontoh kepada orang tuanya. Maka demikian, peranan orang tua sangat penting bagi anaknya sendiri.(Sitorus, 2020).

Kondisi dilapangan sekarang menunjukkan bahwa pembelajaran daring, atau pembelajaran yang dilakukan di rumah dengan bimbingan orang tua pada anak memiliki beberapa masalah, pemahaman orang tua yang kurang terhadap materi, orang tua merasa kesulitan dalam menumbuhkan minat anak untuk belajar, waktu tidak cukup dalam mendampingi anak karena 
harus bekerja, tidak sabarnya orang tua dalam mendampingi anak saat belajar dirumah, orang tua merasa kesulitan untuk mengoperasikan gadget, dan kendala terkait jangkauan layanan internet. (Wardani, n.d.-b). Pembelajaran online bergantung terhadap akses internet dan perangkat yang digunakan untuk pembelajaran sinkronus dan asinknkronus. Masalah lain adalah kedisiplinan anak serta masalah dukungan sosial lainnya. (Jalongo, 2021).

Analisis kendala orang tua dalam mendampingi anak belajar di rumah yang dilakukan oleh para peneliti sangat banyak ketika sebelum adanya pandemi Covid-19, seperti penelitian yang dilakukan oleh Saesti, yang menyatakan bahwa keterlibatan pendampingan orang tua terhadap pembelajaran anak lebih banyak dilakukan dengan guru disekolah, misalnya kegiatan outing class, mini trip, dan market day (Prabhawani, 2016) sehingga kendala orang tua dalam mendampingi anak belajar tidak secara khusus diteliti saat orang tua dan anak berada dirumah, oleh karena itu analisis kendala orang tua dalam mendampingi anak belajar dirumah selama adanya pandemi Covid-19 masih belum banyak dilakukan, walaupun memang sudah ada penelitian mengenai kendala orang tua dalam mendampingi anak belajar dirumah pada masa pandemi Covid-19 seperti ada orang tua yang memberlakukan gadget sebagai sahabat anak ketika anak merasa bosan, kurangnya intervensi orang tua pada dunia anak, masalah orang tua dalam menghadapi anak dan juga kejenuhan orang tua dan anak selama masa pandemi ini (Rohayani, 2020), namun penelitian ini berfokus kepada orang tua anak usia sekolah dasar, bukan secara khusus berfokus kepada orang tua anak dengan usia TK. Untuk itu peran orang tua sangat diperlukan imtuk mendukung keberhasilan pembelajaran dirumah. Anak dengan orang tua yang peduli dengan aktifitas sekolah menjadikan anak lebih banyak menyelesaikan tugas dari pada anak yang orang tuanya tidak mendampingi (Spera, 2005).

Berdasarkan hal tersebut kajian dalam penelitian ini menjadi sangat penting untuk dilakukan dalam memahami bagaimana sebenarnya kendala yang dialami orang tua dalam mendampingi anaknya belajar dirumah menggantikan peran guru saat terjadi pandemi Covid-19 dengan metode pembelajaran daring serta bagaimana penanganan atas kendala-kendala yang dialami orang tua dalam mendampingi anak belajar dirumah dimasa pandemi Covid-19.

\section{METODE}

Metode penelitian yang digunakan dalam penelitian ini adalah kualitatif deskriptif. Penelitian kualitiatif deskriptif adalah berupa penelitian dengan metode atau pendekatan studi kasus (case study). Penelitian ini memusatkan diri secara insentif pada satu obyek tertentu yang mempelajarinya sebagai suatu kasus. Data dari studi kasus dapat diperoleh dari semua pihak yang bersangkutan, dengan kata lain dalam studi ini data dikumpulkan dari berbagai sumber (Nawawi, 2003). Penelitian dilalukan di TK Sekar Nagari Sekaran kelas A dengan 10 anak (10 Ibu) sebagai subjek penetilan. Instrumen penelitian menggunakan teknik trianggulasi yaitu wawancara, dokumentasi dan observasi terhadap subyek penelitian. Penelitian melalukan wawancara kepada Ibu wali murid mengenai kendala yang mereka alami selama mendampingi anak pada masa Pandemi Covid 19. 


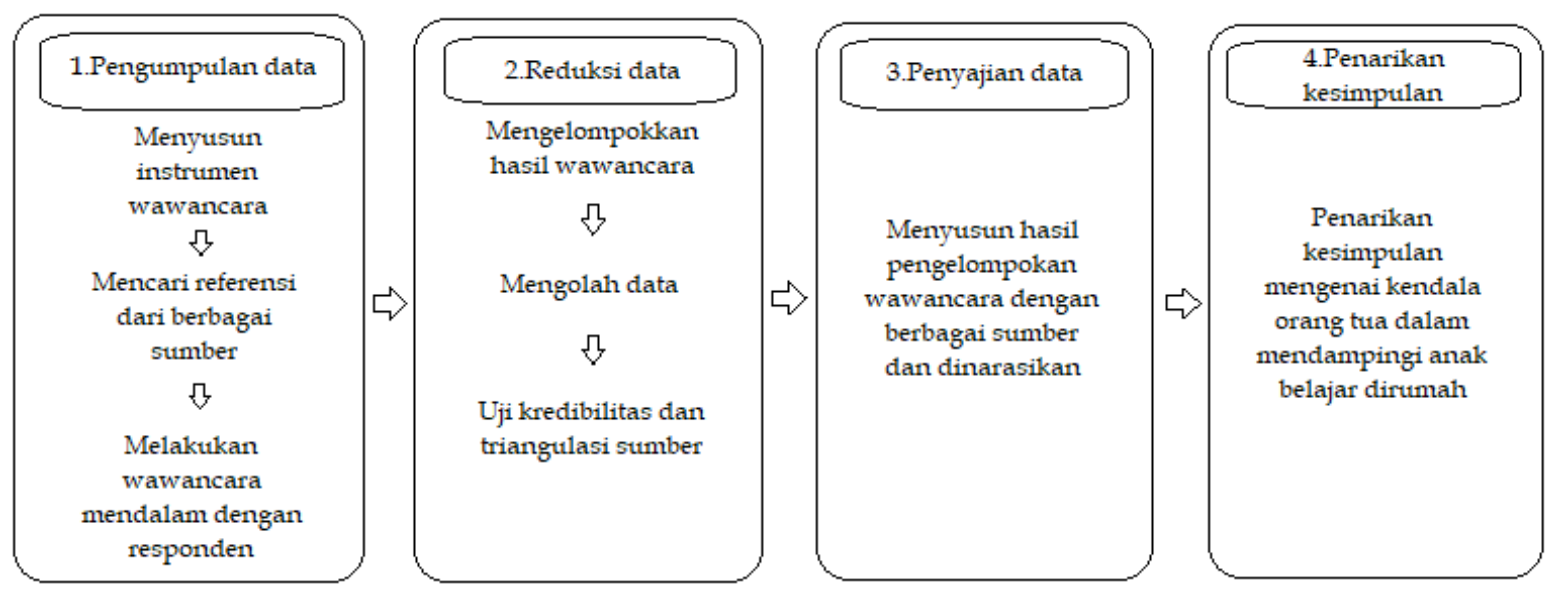

Tabel 1. Langkah-langkah penelitian (Satrianingrum et al., 2021)

\section{HASIL DAN PEMBAHASAN}

Pembelajaran daring selama pandemi Covid-19 memang diharuskan untuk belajar dari rumah (BDR). Meskipun prosesnya berlangsung di rumah, guru akan tetap melakukan evaluasi pada perkembangan anak. Penilaian hasil kegiatan belajar anak dilakukan berdasarkan hasil pengamatan perilaku dan karya yang dibuat anak selama di rumah melalui orang tuanya. Berbagai kegiatan anak di rumah, termasuk semua yang dilakukan oleh anak atau yang dikatakan oleh anak selama belajar dari rumah. Wawancara dilakukan terhadap orang tua atau dengan pendamping belajar anak di rumah untuk memutuskan model fasilitas pembelajaran yang hendak di lakukan.

Orang tua dan anak menjadi lebih aktif dalam berkomunikasi dengan adanya pendampingan dan anak menjadi lebih percaya diri karena apa yang belum ia mengerti bisa langsung ditanyakan. Dalam pembelajaran Anak Usia Dini orang tua perlu menyiapkan smarthphone karena pembelajaran dilaksanakan secara daring melalui aplikasi virtual sesuai dengan jadwal pembelajaran. Guru mengajari anak berbagai materi misalnya menyanyikan lagu - lagu nasional, angggota tubuh serta doa sehari - hari. Beda dngan PAUD B cara pemberian materi ialah dengan pesan Group WhatsAPP guru merekam suaranya melalui perekaman suara lalu dibagikan, anak diharapkan mengikuti arahan dari yang disampaikan oleh gurunya disini orang tua hanya berperan sebagai pengawasan anak dalam melaksanakan pembelajarannya. Salah satu respon orang tua sebagai berikut.

Adanya pembelajaran daring atau online saya mengetahui kemampuan dan gaya belajar anak saya ternyata lebih cepat menangkap pelajaran dengan model visual. Ketika anak diajarkan materi materi visual maka anak sangat antusias sehingga tidak bosan dan menjadi lebih nyaman. Berdasarkan hasil wawancara di atas maka dalam pendampingannya orang tua mampu melihat kelebihan dan kekurangan anaknya dalam menerima pembelajaran di kelas. Dalam wawancara tersebut orang tua dengan teliti mengajari anaknya secara perlahan agar anak bisa menangkap isi dari pembelajaran yang diberikan oleh gurunya. Sehingga strategi yang digunakan oleh orang tua disini ialah teliti dan pelan - pelan dalam mendampingi anak menerima pembelajaran daring.

Wawancara dilakukan terhadap beberapa orang tua dengan latar belakang pekerjaan yang berbeda - beda. Contohnya ketika orang tua sibuk bekerja sebagai pedagang

"Saya disini sangat sibuk berkerja sehari - hari sebagai pedagang di pasar Kobong dan saya sangat tidak punya waktu mendampingi anak - anak saya belajar. Namun sekarang saya sadar 
bahwa pendidikan sengatlah penting. Maka dari itu kami orang tua sebagai pedagang memilih untuk gurunya mengadakan home visit dalam 1 minggu 3 kali menyesuaikan dengan kesanggupan guru dan kondisi anak. Saya disini secara pribadi sangat berterim kasih kepada para Guru telah rela mengajari anak kami dalam melaksanakan pembelajaran."

Strategi yang digunakan oleh orang tua disini adalah menyarankan kapada gurunya untuk berkunjung ke rumah, orang tua menyepakati pembelajaran dilaksanakan dengan tetangga dengan wilayah yang berdekatan maksimal berjumlah 4 orang dengan menggunakan protokol kesehatan yang ketat dan SOP (Standar Oparasional Prosedure) seperti mencuci tangan terlebih dahulu memakai masker dan menjaga jarak sedangkan dalam persesnya pembelajaran dilasanakan satu jam penuh.

\section{SIMPULAN}

Pembelajaran daring di era pandemi covid 19 ini adalah sebuah keniscayaan pada dunia pendidikan. Khususnya Pendidikan Anak Usia Dini memiliki persiapan yang matang dengan melibatkan peran dan fungsi dari para orang tua masing - masing. Maka perlu di pilih strategi yang tepat dalam pelaksanaannya diantaranya dengan melakukan wawancara terlebih dahulu dengan para orang tua dan menyesuaikan latar belakang orang tua yang berbeda - beda. Strategi ini diharapkan mengakomodir kepentingan dan kebutuhan anak dalam pembelajaran yang aman dan nyaman tanpa rasa khawatir dan cemas dalam pelaksanaannya. Standar Oparasional Prosedure atau SOP menjadi pegangan penting dalam praktek pembelajaran dan SOP ini disusun dengan menyesuaikan kebutuhan dan di syahkan secara resmi oleh lembaga. Melalui aktivitas - aktivitas yang tersaji dalam penelitian ini maka strategi pembelajaran daring dapat ditemkan dan menjadi point penting yang solutif khususnya bagi Pendidikan Anak Usia Dini.

\section{DAFTAR PUSTAKA}

Satrianingrum, A., \& Prasetyo, I. (2020). Persepsi Guru Dampak Pndemi Covid-19 Terhadap Pelaksanaan Pembelajaran Daring di PAUD. Jurnal Obsesi: Jurnal Pendidikan Anak Usia Dini, 633-640 doi: 10..31004/obsesi.v5i1.574.

Nawawi, H. (2003). Manajemen SDM Untuk Bisnis yang Kompetitif. Yogyakarta: Gadjah Mada University Press.

Wardani, A. (n.d.-a). Analisis Kendala Orang Tua dalam Mendampingi Anak Belajar di Rumah Pada Masa Pandemi Covid-19,. Jurnal Pendidikan Anak Usia Dini, 5.

Wardani, A. (n.d.-b). Analisis Kendala Orang Tua dalam Mendampingi Anak Belajar di Rumah Pada Masa Pandemi Covid-19. Jurnal Pendidikan Anak Usia Dini, 5

Sitorus, Y. I. Peran Orangtua dalam Membimbing Anak selama Pembelajaran di Rumah sebagai Upaya Memutus Covid-19. JurnalUniversitas Singaperbangsa Karawang. 2020

Prabhawani, S. (2016). Pelibatan Orang Tua Dalam Program Sekolah. FKIP UNY, 1-202.

Rohayani, F. (2020). Menjawab Problematika Yang Dihadapi Anak Usia Dini di Masa Pandemi. Qawwam: Journal For Gender Mainstreaming, Vol. 14, hal. 29-50, doi: 10.20414/Qawwam.v14i1.2310. 
Azra, A. (2000). Pendidikan Islam, Tradisi dan Modernisasi Menuju Milenium Baru, Cet. II. Jakarta: Logos.

Bisri, H. (2013). Landasan Pendidikan. Bandung: Pustaka Setia.

Jaelani, A., dkk. (2020). Penggunaan Media Online Dalam Proses Kegiatan Belajar Mengajar PAI Dimasa Pandemi Covid-19 (Studi Pustaka Dan Observasi Online). Jurnal IKA, Vol. 8 No. 1, Juni 2020 